\title{
An Implicit Cost of Nest Re-use in the Rufous Turtle Dove Streptopelia orientalis
}

\author{
Takeshi WADA \\ Department of Zoology, Faculty of Science, Kyoto University, Sakyo-ku, Kyoto 606 \\ キジバトの古巣利用におけるコスト \\ 和田岳 \\ 京都大学理学部動物学教室
}

Some bird species often re-use old nests for their breedings (HARVEY et al. 1979, NEwTON \& MARquiss 1982, Dow \& FredGa 1983, Shields 1984, Blancher \& Robertson 1985, SONERUD 1985). This behaviour entails potential costs and benefits. The most often mentioned benefit is the time and energy saving realized by not constructing a new nest (BARCLAY 1988, SHIElDS et al. 1988). The costs associated with nest re-using involve food depletion around the nest (NewTON \& MARQuiss 1982, KorPIMÄKI 1987), parasite loads (BROWN \& BROWN 1986, BARCLAY 1988) and risk of nest predation (DOw \& FREDGA 1983, SONERUD 1985).

Some studies examined the predation rate at old nests and showed that previously preyedupon nests were more susceptible to nest predation than ones that were not (Dow \& FREDGA 1983, BLANCHER \& ROBERTSON 1985, SONERUD 1985). This is probably because nest location is remembered by predators, resulting in repeated visits to previously preyed-upon nests (SONERUd \& FJELD 1987, O'ReILly \& HANNON 1989). Such a pattern of nest predation would give previously preyed-upon nests a higher risk of predation. In order to choose better nest sites, birds should know about past events that occurred at the nest before they re-use it.

The Rufous Turtle Dove Streptopelia orientalis often re-uses old nests for breeding (HANEDA \& Nozawa 1969, Murakami \& Fujimaki 1983). Causes of unsuccessful breedings in the dove are neither due to starvation of chicks nor parasites, but mainly due to nest predation and desertion (Murakami \& Fujimaki 1983, NAKao 1984). In the present paper, it is examined whether the same breeding outcome frequently occurs at the same nest, especially following nest predation. Even if previously preyed-upon nests have higher risk of nest predation, the risk may disappear as time goes by, because, for example, the nest predator may cease to revisit the previously preyed-upon nests after several disappointing visits. Therefore, it is also considered whether a longer breeding interval decreases the probability of the same breeding outcome in two successive breedings at a nest.

\section{MATERIALS AND METHODS}

The study was conducted in an area of 6.1 ha of the campus of Kyoto University, Kyoto, Japan, from April 1986 to January 1989. The Rufous Turtle Dove is common in Kyoto all year round, and breeds in a pair which cooperates in nest building, brooding and feeding nestlings (HANEDA \& Nozawa 1969). For successful breedings, it takes 15-16 days from egg-laying to hatching, and 15-17 days from hatching to fledging (HANEDA \& NozAwA 1969, MURAKAMI \& FuJIMAKI 1983). It builds open nests of twigs, mainly on trees and sometimes on buildings, 
although breeding was not observed at nests on buildings. In the study area, tree species included ginkgo Ginkgo biloba, Chinese bottle tree Firniana platanifolia, camphorwood Cinnamomum camphora, ring-cupped oak Quercus glauca, dawn redwood Metasequoia glyptostroboides, Japanese black pine Pinus Thunbergii, Chinese elm Ulmus parvifolia, and others located near buildings and along roads.

The study area was censused at least twice a week in the active breeding season from February to November, and at least once a week in December and January. In every census, all nests detected in the study area were checked, and activities related to breeding, such as nest building and nest site choice, were recorded. Doves were caught with a clapnet or by hands and marked with colour rings, and individual identities were confirmed for each breeding attempt.

In the process of nest site choice, the dove often built several nests before laying eggs. In this paper, nest building and/or behaviours solely involving site choice were not included in analysis of breedings. Only if egg-laying was confirmed or assumed was the event regarded as a breeding and used for the analyses. Each breeding attempt was considered as successful if at least one chick had fledged. Other breeding attempts, which were considered unsuccessful, were divided into three types according to outcome; (1) desertion of a nest containing unhatched eggs, (2) falling of uncracked eggs or uninjured chicks, (3) other failures. Other failures of breedings included cases of fallen egg shells, disappearance of eggs or chicks, injured chicks or broken eggs remaining in nests, or the cases where neither eggs nor chicks were confirmed. Since nests were observed at a distance in order to avoid nest desertion due to disturbance, and breeding pairs seldom left their nests once they started incubating eggs, it was difficult to confirm egg-laying in $41.2 \%$ of 192 breedings. However, even in these cases, egg-laying was assumed if doves continuously sat on nests.

Nests were classified into the following four categories from the view point of re-using; (1) new: newly constructed nests; (2) old-re-used: re-used old nests; (3) old-unknown: old nests without records of previous breedings; (4) others: nests unknown whether new or old, and one nest reconstructed on a nest of Brown-eared Bulbul Hypsipetes amaurotis. Comparisons were conducted only between new and old-re-used. Statistical analyses were two-tailed in most cases, but one-tailed when the outcomes of two successive breedings at a nest were compared, in order to examine the hypothesis that successive outcomes would be the same at the same nests.

\section{RESULTS}

\section{Breeding activity and nest predation}

From April 1986 to January 1989, 192 breeding attempts were recorded almost all year round, with a peak of breeding activity from August to October (Fig. 1). No breeding attempts were initiated in December 1986 and February 1988, but such attempts might be overlooked due to the low frequency of observation in these months.

Some cases of nest predation were observed, as described below. Two species of crows Corvus corone and Corvus macrorhynchos, common in the study area, stole eggs three times. In all of these cases, a crow chose one egg and carried it away. In addition to the above, I observed two cases where a crow approached a nest, just before breeding failures occurred. Nest predations by a cat Felis domestics and a snake Elaphe climacophora were also observed twice and once, respectively. The cats climbed into a nest and ate eggs there, leaving egg shells below the nests. The snake swallowed eggs and left behind a partly destroyed nest. These cases of nest predation were classified as "other failures". Except the nest predation by a snake, the preyed-upon nests were not destroyed by nest predators, nor were any traces of nest predators detected. 


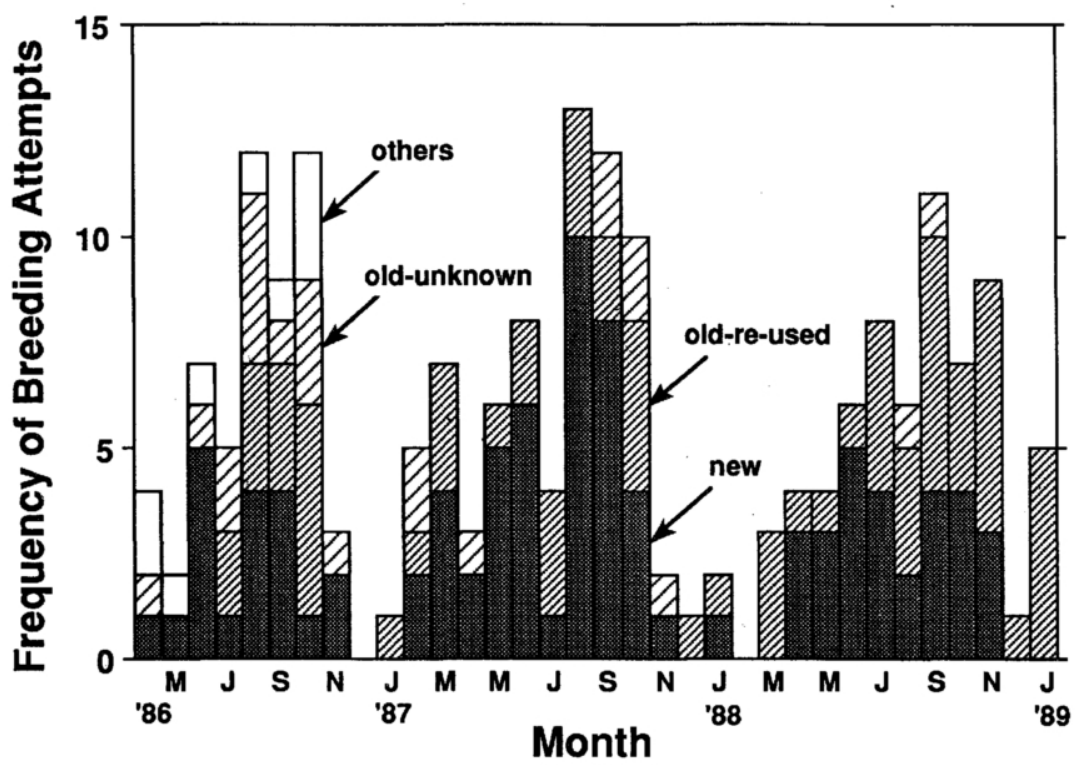

Fig. 1. Seasonal change in breeding activity (April 1986-January 1989). Breeding attempts were put together into each month according to the date of initiation. Nests were classified as new, old-re-used, old-unknown, and others. For details of nest classification, see text.

\section{Old nest re-using}

New nests were used in $47.4 \%$ of all breeding attempts $(n=192)$, old-re-used in $35.9 \%$, old-unknown in $12.0 \%$, and others in $4.7 \%$ of attempts. The ratios of old-re-used to new were significantly higher in 1988 than in $1987\left(\chi^{2}=4.11, P<0.05\right)$ (see Fig. 1).

The doves re-used old nests not only which they themselves had used before, but also which had been used by other individuals. In two successive breedings at the same nests, ones identities of both breeding individuals changed in $34.8 \%$ of all cases, neither changed in $37.7 \%$ of cases, and the rest were uncertain $(n=69)$.

\section{Results of breeding attempts}

Of all breeding attempts $(n=192), 22.9 \%$ resulted in success, $13.0 \%$ in desertion, $3.6 \%$ in falling, and $60.4 \%$ in other failures. The breeding outcomes at new and old-re-used nests are shown in Fig. 2, combining every two months. There were no differences in outcomes between new and old-re-used for each of six seasons and for the total of them (Fisher's exact test, $P>$ 0.1). Seasonal changes in frequency of "other failures" at new and old-re-used nests were significantly correlated $(r=0.763$, d.f. $=4, P<0.05)$, while other outcomes were not $(P>0.1$ for each of them). Fig. 2 obviously shows that "other failures" were more frequent from July to October at both new and old-re-used nests (new: $\chi^{2}=8.00, P<0.01$; old-re-used: $\chi^{2}=6.42, P<$ $0.05)$.

\section{Relationship of breeding outcomes between two successive breedings}

Table 1 shows the relationship of the preceding and the following outcomes in two successive breedings at the same nest, without regarding the interval between breedings. It was examined for each of four breeding outcomes whether the same outcomes tended to occur in the same nests successively. The following outcomes did not tend to be the same as the preceding ones (success after success: 27.3\%, success after other than success: 19.0\%, one-tailed Fisher's exact 


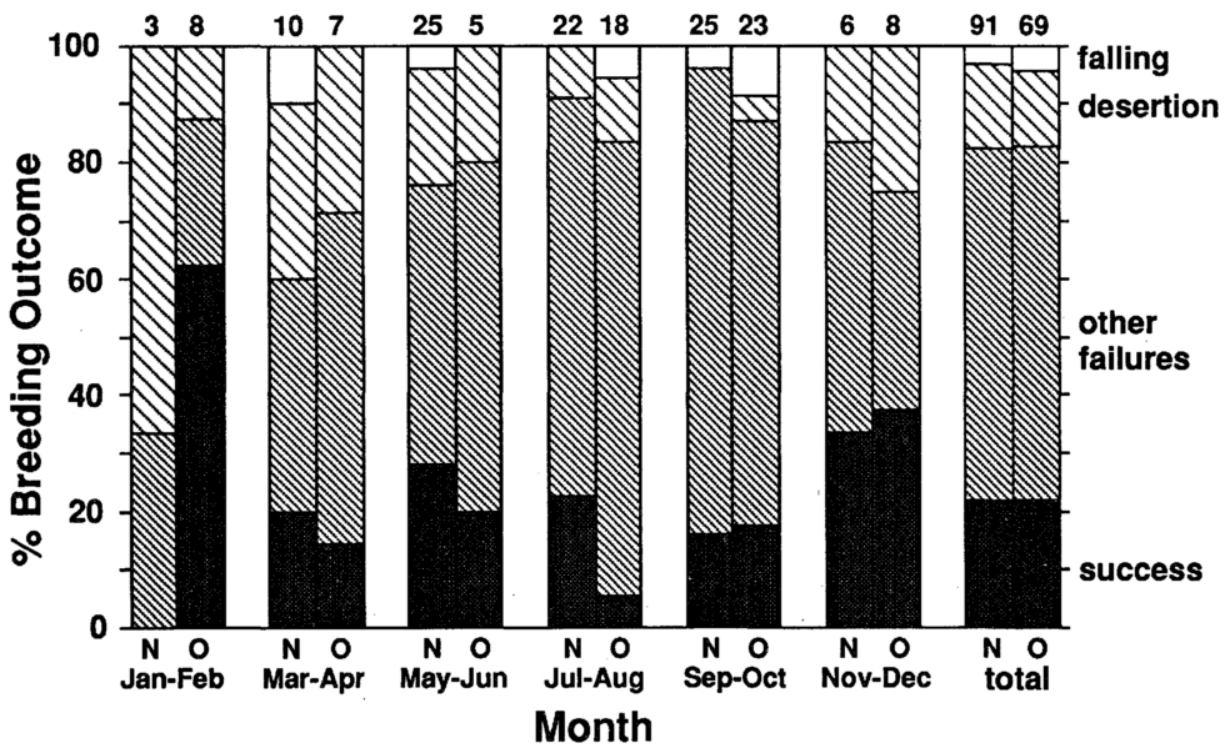

Fig. 2. Seasonal change in breeding outcomes at new (N) and old-re-used (O) nests. Breeding outcomes were classified as success, desertion, falling and other failures. Figures above each bar show sample sizes.

Table 1. Relationships between the preceding and the following outcomes of two successive breedings.

\begin{tabular}{|c|c|c|c|c|c|}
\hline \multirow{2}{*}{$\begin{array}{l}\text { Preceding } \\
\text { breeding }\end{array}$} & \multicolumn{4}{|c|}{ Following breeding } & \multirow{2}{*}{ Total } \\
\hline & Success & Desertion & Falling & Others & \\
\hline Success & 3 & 0 & 0 & 8 & 11 \\
\hline Desertion & 0 & 4 & 0 & 5 & 9 \\
\hline Falling & 1 & 2 & 0 & 0 & 3 \\
\hline Others & 10 & 4 & 3 & 29 & 46 \\
\hline Total & 14 & 10 & 3 & 42 & 69 \\
\hline
\end{tabular}

test, $\boldsymbol{P}>0.1$ ), for desertion ( $44.4 \%$ and $10.0 \%$ respectively, one-tailed Fisher's exact test, $P>$ $0.1)$, for falling $(0.0 \%$ and $4.5 \%$ respectively, one-tailed Fisher's exact test, $P>0.1)$, and for other failures $\left(63.0 \%\right.$ and $56.5 \%$ respectively, one-tailed $\chi^{2}$ test, $\left.\chi^{2}=0.27, P>0.1\right)$.

The interval between two successive breedings at a nest is defined here as the number of days counted from the day at the end of the preceding breeding to the day of egg-laying of the following attempt at the same nest, regardless of the identities of the breeding individuals. The interval ranged from 2 to 524 days (mean $=118.1$, s.d. $=125.2$ ). Only $8.7 \%$ were longer than a year (6 out of 69 ), and $79.7 \%$ were shorter than a half year (55 out of 69 ).

Whether the same breeding outcomes tended to occur frequently at the same nests in succession was examined in regard to varying breeding intervals (Fig. 3). The percentage of success in successive breedings was not significantly higher than that of the occurrence of different outcomes for every interval. However, the percentage of "other failures" was significantly higher for intervals of less than 30 days and 60 days (one-tailed Fisher's exact test $P<0.05)$. 
(a) Success

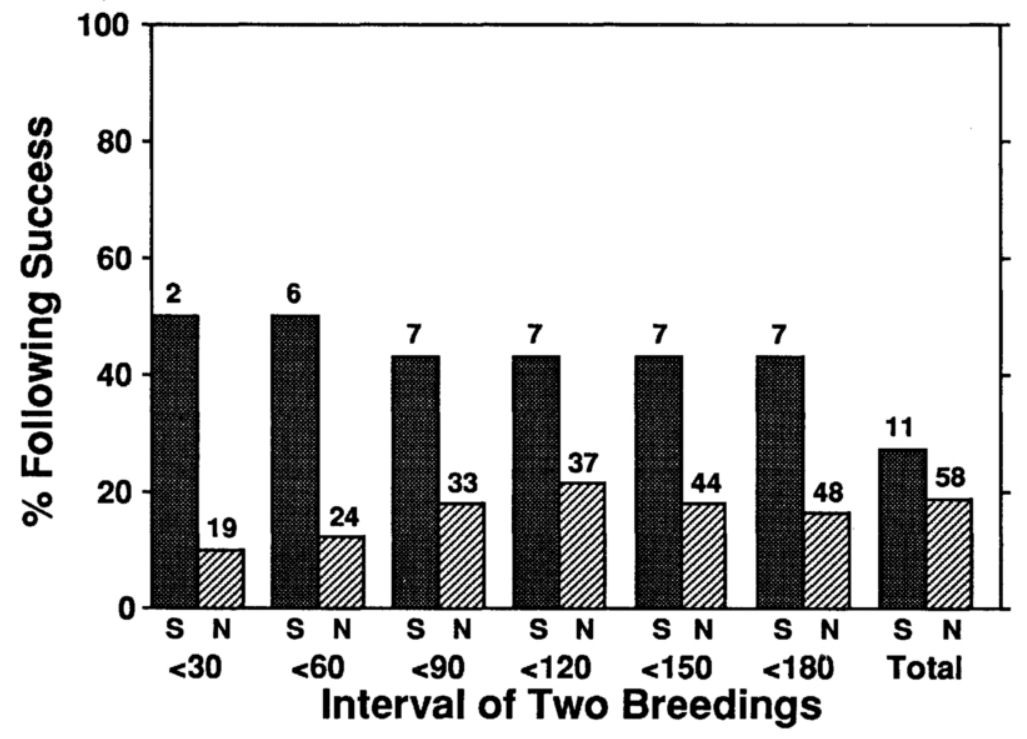

(b) Other Failures

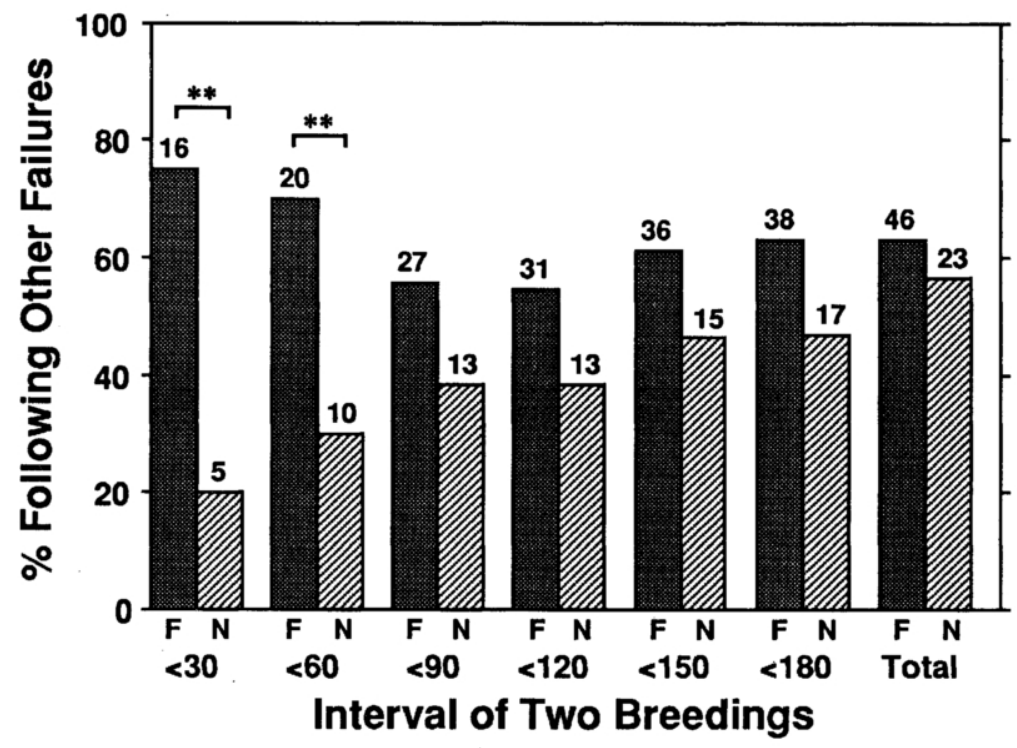

Fig. 3. The percentages of occurrence of the same and different outcomes as the preceding one for "success" and "other failures", with regard to breeding interval. The preceding breeding outcomes were plotted on the horizontal axis as "success" (S) or not successful (N), and "other failures" (F) or not (N). **: $P<0.05$ by one-tailed Fisher's exact test. Figures above each bar show sample sizes. 


\section{DISCUSSION}

Fig. 3 showed that the same outcomes occurred in successive breedings when other failures occured in the preceding breedings within a 60 day interval. Other failures occurred, however, more frequently from July to October both at new and old-re-used nests (Fig. 2), suggesting that the result may only reflect a seasonal tendency in breeding outcome at old-re-used nests. Among successive breedings examined in Fig. 3(b) with an interval of less than 60 days, the percentage initiated from July to October was $75.0 \%$ for those with the same preceding breeding outcome, and $60.0 \%$ for those with a different outcome (Fisher's exact test, $P>0.1$ ). This means that the results shown by Fig. 3 do not reflect only a seasonal tendency of other failures.

The causes of unsuccessful breeding were difficult to determine in many cases. In this study, a few cases of failure were ascertained to be the result of nest predation, and were classified as "other failures". However, most of the outcomes, such as fallen egg shells, disappearance of eggs or chicks, injured chicks or broken eggs remaining in nests included in "other failures" must be caused by nest predation. Therefore, it is probable that most of "other failures" were caused by nest predation.

If previously preyed-upon nests suffered high predation pressure compared to others, this may generally be explained in two ways. First, nest predators may tend to revisit previously preyed-upon nests, and second, the nests may have characteristics susceptible to nest predation. If the second case occurs, previously preyed-upon nests should be more susceptible to nest predation regardless of breeding interval. The results obtained in Fig. 3 were contrary to the second explanation. Thus, the former may be a more likely explanation.

The difficulty of the first causation is in explaining the fact that the rate of the same outcomes in the following breedings for "other failures" within a 60 day interval $(70.0 \%$, Fig. 3) was not much higher than "other failures" at new nests $(60.4 \%$, Fig. 2). This can be explained by assuming high susceptibility of new nests to nest predation, compared to old-re-used nests not preyed-upon within 60 days. A probable factor causing this is related to nest building activity. Most breedings as new nests were detected by the observer by nest building activities, and this may be also true for nest predators. This possibility is also suggested for other birds (Collias \& Collias 1984), though it needs more investigation.

Repeated nest predation at the same nests was also reported for Goldeneyes Bucephala clangula (Dow \& FREDGA 1983), Eastern Kingbirds Tyrannus tyrannus (BlANCHER \& RoBERTSON 1985), and Tengmalm's Owl Aegolius funereus (SONERUD 1985), but these studies did not distinguish the two possible explanations for high predation pressure at the same nests. In these studies, repeated nest predation occurred even after one year, a period much longer than that of the present study. This difference can be explained in two ways; firstly, the second cause described above can be applied to the results of the other studies, and secondly, nest predators of the dove cease to revisit previously preyed-upon nests within a shorter period than other species. The latter is probable because the extended breeding season of the dove makes it difficult to estimate the period of the next breedings of already preyed-upon nests and lowers the expectation of each predator's visit, whereas the next breedings in other species can be expected about a year after due to their fairly restricted breeding seasons.

It is important for doves to assess the risk of nest predation in choosing nest sites, since it may be one of the most important factors affecting breeding success. If previously preyed-upon nests are more susceptible to nest predation, past nest predation should be assessed by the present condition of an old nest before doves choose to use it. However, since any traces of past nest predations were not detected in this study, it seems impossible for doves to assess past nest 
predation at an old nest, unless they themselves were the previous users. Thus, re-use of old nests previously used by other pairs includes an implicit cost. This situation is interesting in that the information about the quality of nest sites concerning previous nest predation is open not for all birds, but only for the individuals which previously used the nests. In spite of the implicit cost of nest predation, doves often re-used old nests previously used by other pairs. Then, it should be studied when and how the doves run the implicit risk of nest predation in re-using old nests used by other pairs.

\section{ACKNOWLEDGEMENTS}

I am grateful to Y. EZAKI for his advice in conducting this study, to H. KAWANABE for his critical comments, and T. ABE, K. IWASAKI and K. NAKAI whose readings helped improve this paper. I also thank the members of the Laboratory of Animal Ecology of Kyoto University for their constructive comments. I am grateful to L. Turner for revision of the English. This study was partly supported by the Grant-in-Aid for General Scientific Research (No. 61480005) from the Japan Ministry of Education, Science and Culture. This paper is the contribution from the Laboratory of Ecology, Department of Zoology, Kyoto University, No. 532.

\section{SUMMARY}

1) The Rufous Turtle Dove Streptopelia orientalis was studied in Kyoto, Japan and found to often re-use old nests for breeding. The hypothesis that the same breeding outcome (success or failure due to different causes) tended to occur at the same nest was examined with reference to the interval between two successive breedings.

2) Seasonal tendencies in breeding outcomes were not significantly different between new and old-reused nests. "Other failures" were most frequent in July to October, both at new and old-re-used nests.

3) "Other failures" occurred more frequently at the nests in which the preceding outcomes were also "other failures" within a certain breeding interval, but there was no such relationship for successful breedings. The tendency was diminished when all breedings were combined with no consideration of breeding interval.

4) The results obtained here suggested that nest predators tended to revisit previously preyed-upon nests within a certain interval. It is suggested that, as the risk of nest predation in using old nests could not be assessed by the present status of the nests, re-use of old nests involves an implicit cost of nest predation.

\section{要 約}

京都においてキジバト Streptopelia orientalis の古巣を利用した繁殖について研究した. 古巣が再利 用された場合，以前と同じ繁殖結果が得られるかという仮説をその巣が再び利用されるまでの時間間 隔を考虑して検討した.

新しく造られた巣と再利用された古巣との間に, 繁殖結果の季節的傾向に違いはなく，どちらの巣 においてもある種の繁殖の失敗 (other failure) は 7-10月に頻繁に生じた.

以前の繁殖が other failure であった巣が 60 日以内に再び繁殖に利用された場合, 再び other failure が生じる傾向があった. 一方, 繁殖成功に関しては同様の傾向は見られなかった. また, 栄が再び利 用されるまでの時間間隔を考慮しなければ, 同じ巣で同じ繁殖結果が再び生じるという傾向はなかっ た. Other failure の原因の多くは捕食であると考えられ，この結果は巣の捕食者が一度捕食した巣を ある時間間隔内で再び訪れる傾向があるということを示唆していると考えられた. 


\section{LITERATURE CITED}

BARCLAY, R. M. R., 1988. Variation in the costs, benefits, and frequency of nest reuse by barn swallows (Hirundo rustica). Auk 105: 53-60.

Blancher, P. J. \& Roberston, R. J., 1985. Site consistency in kingbird breeding performance: implications for site fidelity. J. Anim. Ecol. 54: 1017-1027.

Brown, C. R. \& Brown, M. B., 1986. Ectoparasitism as a cost of coloniality in cliff swallows (Hirundo pyrrhonota). Ecology 67: 1206-1218.

Collias, N. E. \& Collias, E. C., 1984. Nest building and bird behavior. Princeton, Princeton University Press.

Dow, H. \& FredGA, S., 1983. Breeding and natal dispersal of the goldeneye, Bucephala clangula. J. Anim. Ecol. 52: 681-695.

Haneda, K. \& Nozawa, S., 1969. A study on the life history of Streptopelia orientalis. 1. Breeding cycle. J. Yamashina Inst. Ornithol. 5: 473-486. (In Japanese with English summary.)

Harvey, P. H., Greenwood, P. J. \& Perrins, C. H., 1979. Breeding area fidelity of great tits (Parus major). J. Anim. Ecol. 48: 305-313.

KORPIMÄKI, E., 1987. Selection for nest-hole shift and tactics of breeding dispersal in Tengmalm's owl Aegolius funereus. J. Anim. Ecol. 56: 185-196.

Murakami, J. \& Fujimaki, Y., 1983. Breeding biology of rufous turtle dove Streptopelia orientalis in the Tokachi District, Hokkaido. Tori 31: 95-106. (In Japanese with English summary.)

NAKAO, H., 1984. Fluctuations in population density and breeding performance of the rufous turtle dove Streptopelia orientalis in Hokkaido. Jap. J. Appl. Ent. Zool. 28: 193-200. (In Japanese with English summary.)

Newton, I. \& MARQUiss, M., 1982. Fidelity to breeding area and mate in sparrowhawks Accipiter nisus. J. Anim. Ecol. 51: 327-341.

O'Reilly, P. \& Hannon, S. J., 1989. Predation of simulated willow ptarmigan nests: the influence of density and cover on spatial and temporal patterns of predation. Can. J. Zool. 67: 1263-1267.

SHIELDS, W. M., 1984. Factors affecting nest and site fidelity in Adirondack barn swallows (Hirundo rustica). Auk 101: 780-789.

Shields, W. M., Crook, J. R., Hebblethwaite, M. L. \& Wiles-Ehmann, S. S., 1988. Ideal free coloniality in the swallows. In SLobodchixoff, C. N. (ed.), The ecology of social behavior: 189-228. London, Academic Press.

Sonerud, G. A., 1985. Nest hole shift in Tengmalm's owl Aegolius funereus as defense against nest predation involving long-term memory in the predator. J. Anim. Ecol. 54: 179-192.

SONERUD, G. A. \& FJELD, P. E., 1987. Long-term memory in egg predators: an experiment with a hooded crow. Ornis Scand. 18: 323-325.

(Accepted 10 November 1991) 